\title{
The Use of Antimicrobial and Antiviral Drugs in Alzheimer's Disease
}

\author{
Umar H. Iqbal, Emma Zeng and Giulio M. Pasinetti * \\ Department of Neurology, Icahn School of Medicine at Mount Sinai, New York, NY 10029, USA; \\ umar.iqbal@mssm.edu (U.H.I.); emma.zeng@mssm.edu (E.Z.) \\ * Correspondence: giulio.pasinetti@mssm.edu; Tel.: +1-212-241-7938
}

Received: 29 May 2020; Accepted: 10 July 2020; Published: 12 July 2020

\begin{abstract}
The aggregation and accumulation of amyloid- $\beta$ plaques and tau proteins in the brain have been central characteristics in the pathophysiology of Alzheimer's disease (AD), making them the focus of most of the research exploring potential therapeutics for this neurodegenerative disease. With success in interventions aimed at depleting amyloid- $\beta$ peptides being limited at best, a greater understanding of the physiological role of amyloid- $\beta$ peptides is needed. The development of amyloid- $\beta$ plaques has been determined to occur 10-20 years prior to AD symptom manifestation, hence earlier interventions might be necessary to address presymptomatic AD. Furthermore, recent studies have suggested that amyloid- $\beta$ peptides may play a role in innate immunity as an antimicrobial peptide. These findings, coupled with the evidence of pathogens such as viruses and bacteria in AD brains, suggests that the buildup of amyloid- $\beta$ plaques could be a response to the presence of viruses and bacteria. This has led to the foundation of the antimicrobial hypothesis for AD. The present review will highlight the current understanding of amyloid- $\beta$, and the role of bacteria and viruses in $\mathrm{AD}$, and will also explore the therapeutic potential of antimicrobial and antiviral drugs in Alzheimer's disease.
\end{abstract}

Keywords: Alzheimer's disease; amyloid- $\beta$; antimicrobial; antiviral; antimicrobial peptide

\section{Alzheimer's Epidemiology}

Alzheimer's disease (AD) is a progressive neurological disorder that accounts for the greatest number of dementia cases. As of 2019, 5.8 million people were living with AD, with its prevalence predicted to increase to 13.8 million by 2050 [1]. The vast majority of cases are concentrated in ages over 65 , impacting $10 \%$ of people in this age group. In addition, the economic toll of AD on the United States economy is significant, estimated to be roughly USD 290 billion in 2019 [1]. As the number of cases is only expected to rise over the coming decades, research in this field is critical in order to understand the pathology of this disease, as well as potential therapeutics.

\section{Timeline/Characterization of Alzheimer's Disease}

The understanding and characterization of $\mathrm{AD}$ can be traced back over 100 years to Alois Alzheimer, from whom the disease takes its name. After completing an autopsy of a patient with progressive dementia, Alzheimer noticed a severe amount of cortical degeneration and an accumulation of protein deposits, specifically extraneuronal plaques and intraneural tangles [2]. By 1991, the buildup of extraneuronal amyloid- $\beta(A \beta)$ plaques became the hallmark trait of the pathogenesis of Alzheimer's disease [3], initiating the development of the amyloid cascade hypothesis [4]. In parallel to A $\beta$ plaques formation, the accumulation of other naturally unfolded proteins is central to $\mathrm{AD}$ and other cerebral proteopathies [5]. The intracellular aggregation of tau proteins in the form of neurofibrillary tangles (NFTs) is also an essential trait in the pathogenesis of Alzheimer's disease [3,6]. A recent 2020 study 
found that neuroinflammation could play a role in the aggregation of tau, as DNA extracted from various bacterial species promoted tau misfolding [7]. Whereas $\mathrm{A} \beta$ plaques are more critical to $\mathrm{AD}$ pathogenesis, the tau protein appears to be more responsible for subsequent cognitive impairment and dementia symptoms associated with AD [8]. Indeed, tau hyperphosphorylation and NFT levels are closely correlated with cognition, and exhibit potential as therapeutic targets for AD treatment [9]. Furthermore, tau protein production has been shown to have a positive correlation with the production of $A \beta$ plaques [10], with the formation and lack of clearance of $A \beta$ plaques also being proposed to induce tau protein formation into NFTs [11]. Coupling this with the bi-directional relationship between $A \beta$ plaques and neuroinflammation [12] would cement $A \beta^{\prime}$ s key role in driving $A D$ pathology.

\subsection{Amyloid- $\beta$ Generation}

$A \beta$ formation begins with the breakdown of the amyloid precursor proteins (APP) embedded in the membranes of cells, such as neurons, as a type 1 transmembrane glycoprotein [13]. A $\beta$ peptides are produced through a two-step cleavage process, in which APP is metabolized into smaller fragments. In the first step, APP is cleaved by $\beta$-secretase 1 into a membrane-bound CTF $\beta$ fragment (containing 99 amino acids) and an extracellular fragment SAPP $\beta$. CTF $\beta$ is then further cleaved by $\gamma$-secretase to create the final $A \beta$ peptide [13-15], as illustrated in Figure 1. The length of $A \beta$ peptides is not fixed, and can consist of anywhere between 37 and 49 amino acids, depending on where the cleavage was done by $\beta$-secretase 1 and $\gamma$-secretase $[16,17]$. The most abundant length is $A \beta_{1-40}$, representing approximately $80-90 \%$ of $A \beta$ peptides, whereas the least soluble of the $A \beta$ peptides, $A \beta_{1-42}$, represents roughly $5-10 \%[13,15]$. As a greater number of $A \beta$ peptides form, they begin to aggregate into oligomers, which then form fibrils, and eventually the insoluble plaques characteristic of $\mathrm{AD}$ [13]. Of the different isoforms of $\mathrm{A} \beta$ peptides, $A \beta_{1-40}$ and $A \beta_{1-42}$ are the most common in plaques. Regarding the comparative role of $A \beta_{1-40}$ and $A \beta_{1-42}$ peptides in the pathogenesis of $A D, A \beta_{1-42}$ peptides have been found in higher concentrations in AD. Furthermore, $A \beta_{1-42}$ peptides have been found to be more prone to forming insoluble amyloid fibrils than $A \beta_{1-40}$ [18]. This is further supported by a study using transgenic mice that expressed either $A \beta_{1-40}$ (BRI- $A \beta 40$ ) or $A \beta_{1-42}$ (BRI- $\left.A \beta 42 A\right)$. The authors found that the mice that selectively expressed $A \beta_{1-40}$ did not develop AD pathology at any age. However, the same did not hold true for BRI- A $\beta 42 A$ mice, which had developed $A \beta$ deposits [19]. In addition, another study found $A \beta_{1-42}$ peptides to promote $A \beta$ plaques formation, and $A \beta_{1-40}$ to decrease $A \beta$ deposition [20]. These findings would indicate the key role $\mathrm{A} \beta_{1-42}$ peptides play in the pathogenesis of $\mathrm{AD}$.

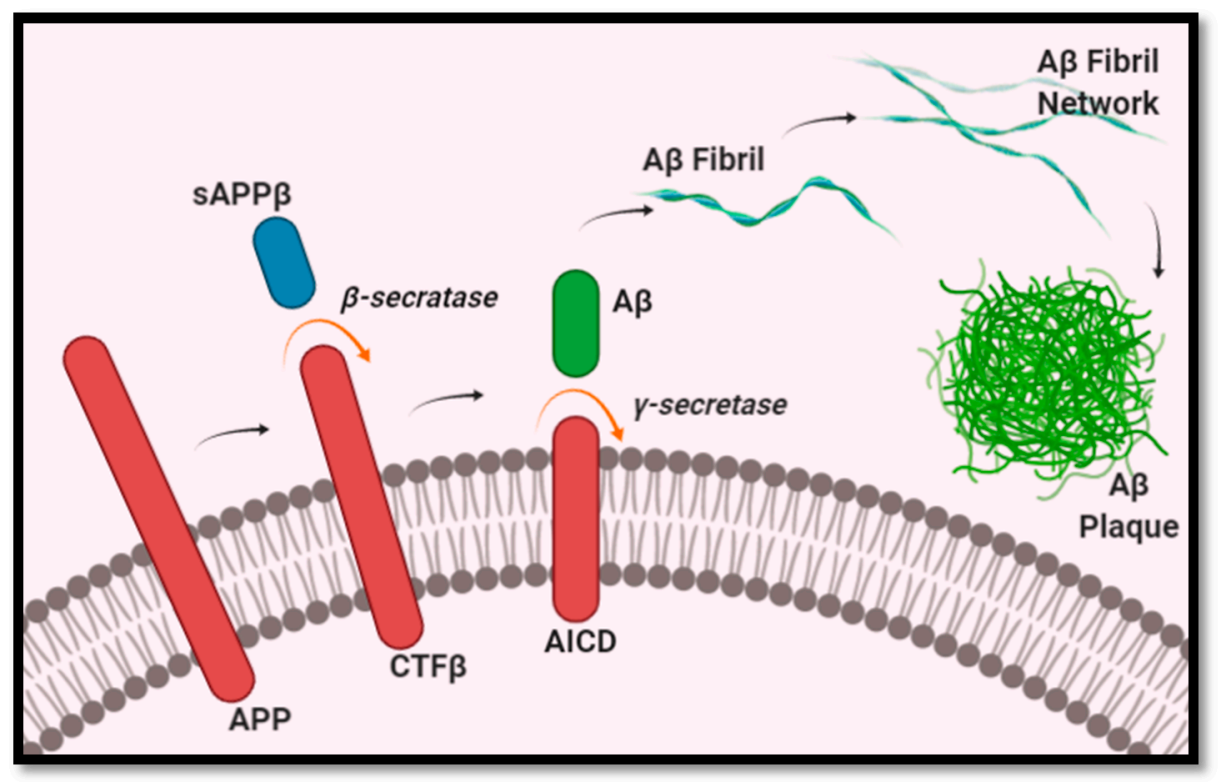

Figure 1. Generation of $A \beta$ plaques. 


\subsection{Current Interventions and Limitations}

Even with the tremendous effort that has been put into developing potential therapies for AD over the past few decades, there has been little success in reaching an effective therapy, with no new drug being approved in over a decade. While cholinesterase inhibitors and memantine are FDA-approved drugs for $\mathrm{AD}$, and do address some of its symptoms, they lack the ability to attenuate disease progression. Over the past 20 years, a majority of the therapies have been based on the amyloid cascade hypothesis, and hence have focused on depleting $A \beta$ peptides. Theses therapies often aim to inhibit $\gamma$-secretase or $\beta$-secretase activity in order to limit $A \beta$ peptide production. Therapies that use such methods have, however, seen an increase in the rate of infection during clinical studies, with one study seeing $6 \%$ of participants develop meningoencephalitis [21,22]. Tarenflurbil, for instance, had been administered clinically, after it was shown to modulate $\gamma$-secretase and increase production of the less toxic $A \beta_{1-38}$ peptide, rather than $A \beta_{1-42}$ peptide [23,24]. However, in addition to not showing any significant benefit in individuals with mild $\mathrm{AD}$, participants in the treatment group experienced an increase in upper respiratory infections and dizziness compared to the placebo group [25]. Additionally, in the time of COVID-19 infection, respiratory-related side effects, such as the ones related to tarenflurbil, are of growing concern. The $\gamma$-secretase inhibitor Semagacestat has not only been associated with increased levels of infection, but also with a failure to provide any cognitive improvement in patients with probable AD [26]. Furthermore, when patients with mild to moderate AD were administered ELND005, a compound that inhibits $A \beta$ fibrils and plaque formation, it was observed that higher doses of this treatment led to serious infection. This led to lower dosage recommendations for future trials $[27,28]$. Lastly, the B-site ABPP cleaving enzyme 1 (BACE1)-inhibitor E2609 has also been associated with oralabial herpes relapse [29,30]. A rise in infection occurring in tandem with the reduction of $A \beta$ peptide production could indicate these peptides' potential role in immune function.

Through these past clinical trials, it is evident that therapies largely based on the amyloid cascade hypothesis, which in turn aim to eradicate $\mathrm{A} \beta$ peptides in the brain, have historically been ineffective. These failures could imply that current approaches either intervene at a stage that is too late, or possess a therapeutic target that is not as relevant to disease progression [31]. This would make sense in the context of $\mathrm{AD}$ especially, as $\mathrm{A} \beta$ deposition occurs 10-20 years before the occurrence of clinical symptoms [32]. Therefore, these treatments that target $A \beta$ peptides specifically may already be too late. To create a successful therapy, it may be necessary to consider intervention in the presymptomatic stage of the AD instead. To do so, it would be crucial to identify biomarkers for early identification of AD. In March of 2016, a meeting was convened in which international, interdisciplinary experts identified a list of biomarkers that could be used for identifying AD early on [33]. CSF levels of $A \beta_{1-42}$ and $A \beta_{1-40}$, and the ratio of $A \beta_{1-42} / A \beta_{1-40}$, were determined to be among the candidates $[33,34]$. In addition, plasma levels of the same biomarkers were determined to decrease in AD patients when compared to healthy subjects [35]. Other biomarkers to consider would include plasma levels of tau protein and neurofilament light [33]. Plasma levels of the latter have been shown to be able to detect neurodegeneration in presymptomatic AD [36]. Other highly sensitive methods that have shown promise in the early identification of $A D$ include protein misfolding cyclic amplification (PMCA) and real-time quaking-induced conversion (RT-QuIC), to determine A $\beta$ oligomers and tau protein levels in CSF $[37,38]$. Taking a more preventative approach to $\mathrm{AD}$ treatment, and understanding and addressing factors that contribute to the progression of $\mathrm{AD}$, may be favorable for identifying therapeutic targets earlier in the disease. Based on evidence of the association between bacterial/viral infection and AD progression, the antimicrobial hypothesis suggests that $\mathrm{A} \beta$ peptides may be produced as a protective mechanism by the innate immune system, and act as an antimicrobial peptide (AMP) against foreign agents. If $A \beta$ peptides do in fact play a beneficial role in immunity, then the aim of treatment should not be to eradicate the compound entirely. Rather, it should be to target the root cause of its over production, and reduce its deleterious effects and general neuroinflammation in AD. 


\section{Antimicrobial Protection Hypothesis}

\subsection{Role of Microorganisms and Viruses in $A D$ and $A \beta$ Generation}

Neuroinflammation is inflammation within the brain or spinal cord due to infection, toxins or injury [39]. In the brain specifically, resident glial cells, such as microglia and astrocytes, along with endothelial cells and mast cells, all aid in defending the brain against foreign pathogens [40]. Microglia, the main immune effector cells of the central nervous system (CNS), are constantly surveying their environment for potential threats to the brain [41,42]. When an invading agent is detected, microglia change into an activated state, characterized by an enlarged soma and the production of inflammatory cytokines and chemokines [39]. Astrocytes also play a critical role in mediating neuroinflammation as they are responsible for many neuroprotective functions, such as maintaining blood brain barrier (BBB) integrity and buffering neurotransmitters [43]. Upon injury, astrocytes likewise undergo morphological changes, and exhibit increased reactivity and secretion of cytokines and chemokines [41]. While acute inflammatory responses are common to healthy individuals, chronic inflammation is damaging to the natural balance of pro- and anti-inflammatory signaling in the brain, and can lead to the development and progression of neurodegenerative diseases like AD [39].

Over the years, there has been increasing evidence of neuroinflammation's role in AD. In addition to $A \beta$ plaques and NFTs, markers of sustained inflammation and microglial activation have repeatedly been found in AD brain samples [39]. The cytokines interleukin 1 and interleukin 6 are especially elevated [44]. One source of the neuroinflammation in AD patients could be the response to invading microorganisms and viruses. In fact, researchers have found evidence pointing to the presence of pathogens, such as viruses, bacteria and fungi, in AD brains [45-50]. This notion draws parallels with the measles virus, which can lead to the development of the neurological disease known as subacute sclerosing panencephalitis [51]. These findings include the identification of viral [52] and bacterial DNA in post-mortem brain samples, and the detection of pathogens [53] and/or their respective antibodies [54] in the serum or cerebrospinal fluid of patients. Furthermore, detection of lipopolysaccharide is commonly used by researchers to measure the presence of Gram-negative bacteria, like $P$. gingivalis specifically, as it is found in their cell walls and can stimulate an inflammatory response in the immune cells [42]. Herpes simplex virus-1 (HSV-1) [52,55-58] was the first pathogen found to be present in AD brain samples [59], and it thereafter became the most widely-researched pathogen regarding the linkage between viral infection and AD. Since then, other viruses have been identified in leading to the progression of $\mathrm{AD}$, including human cytomegalovirus [54] and Epstein Barr Virus [60]. A recent 2018 study found that, in addition to HSV-1, herpesvirus types HHV-6 [46,47] and HHV-7 were highly present in AD patients [61]. In this study, by Readhead et al., HHV-6 and HHV-7 were also observed to be involved in regulatory processes critical to characteristic features of the disease [61].

Bacterial infection has likewise been associated with the progression of $\mathrm{AD}$. The presence of bacteria in the brain has been determined in previous studies, suggesting the presence of a brain microbiome [62-64]. Even though bacterial presence has been seen in the brains of healthy individuals, tissue samples from AD brains have greater levels of bacterial species [64], indicating a greater level of infiltration. Chlamydia pneumoniae is the most widely-studied bacteria regarding association to AD [25,49]. A clinical investigation, made up of a healthy control group and an $\mathrm{AD}$ group, detected C. pneumoniae in $90 \%$ of the AD patients, whereas the control group were all negative [53]. Escherichia coli, likewise identified in AD brains [65], has been found to be capable of synthesizing extracellular amyloid [66]. Stains such as Borrelia burgdorferi [67], spirochetes [48], and Porphyromonas gingivalis, a pathogen commonly linked to chronic periodontitis, have also been identified in AD brain samples [68].

Interestingly, fungal infection from species primarily associated with periodontal disease has recently been suggested to be involved in AD progression. Researchers in a 2014 study detected multiple fungal species in AD brain samples, including Saccharomyces cerevisiae, Malassezia globosa, Malassezia restricta, Penicillium and Phoma [69]. Pisa et al. have since followed up on this initial discovery 
by analyzing the presence of these species between brain regions [70]. With any of these studies that have been conducted, however, it is important to recognize the technical limitations that arise when studying microorganisms and neurodegenerative disease. Many of these studies are limited to the use of post-mortem brain samples, and thus present the risk of contamination due to death or the passage of microbes from other areas of the body, such as the gut to the brain, due to the lack of a functioning BBB to prevent this leakage.

\subsection{Invasion of the CNS and Role in $A \beta$ Generation of AD-Associated Microorganisms and Viruses}

Depending on the organism, there are several ways that pathogens can infiltrate the CNS and potentially further the progression of AD. The first is through a compromised BBB. Whereas a healthy and functional BBB normally provides a selective barrier to the passage of cells and molecules into the brain, a compromised BBB can allow direct entry into the cerebral spinal fluid via the bloodstream [21]. This places aging populations and those with weakened immune responses especially at risk, as some viruses, such as herpesvirus, can remain latent after initial infection and then reactivate in aging individuals long after, to introduce delayed adverse complications [71]. Even with a healthy BBB, however, bacteria and viruses are still able to be introduced into the brain through various mechanisms. HIV, for example, is carried from the immune system to the brain by infected leukocytes that are able to cross the BBB. P. gingivalis and other oral spirochetes have also been suggested to be capable of invading the CNS via the oral cavity, through the trigeminal nerves and ganglia [42]. Additionally, pathogens such as bacteria and viruses can bypass the BBB altogether by entering through the olfactory system, as the nasal cavity connects the peripheral environment to brain regions such as the olfactory bulb [72], the entorhinal cortex and the hippocampus, which traditionally receive smell sensory signals. C. pneumoniae, a respiratory pathogen, has specifically been suggested to enter the brain through the olfactory system, with its presence detected in the entorhinal cortex and hippocampal formation of $\mathrm{AD}$ patients [73]. A recent 2020 study model demonstrated that exposure to $C$. pneumoniae via the olfactory system was sufficient to induce $A \beta$ plaque and NFT formation in the olfactory cortex and hippocampus of immunocompromised individuals [74]. This is further evidenced by Little et al., who found that intranasal inoculation of C. pneumoniae was sufficient to induce AD-like traits in mice [75]. Once in the brain, there are several ways in which these pathogens contribute to the $A \beta$ production that is characteristic to $A D$. One mechanism is through the alteration of gene expression. The study previously mentioned by Readhead et al. found that HHV-6 and HHV-7 interact with known regulatory genes responsible for amyloid processing, such as the amyloid beta A4 precursor protein-binding family (APBB2), clusterin (CLU), and gamma-secretase subunit presenilin-1 (PSEN1) [61]. Similarly, infection of C. pneumoniae within human neuronal cell cultures possibly alters calcium-related gene expression such that they express patterns similar to those reported in $\mathrm{AD}$ brain samples [76]. Another way viruses can influence $A \beta$ production is through protein misfolding. Specifically, viruses such as HHV, cytomegalovirus and Epstein Barr Virus have been shown to contain prion-like domains that may trigger the misfolding of proteins like $\mathrm{A} \beta$ [77]. Through these varying mechanisms, many microorganisms and viruses have been found to initiate $\mathrm{A} \beta$ plaque formation.

In-vivo studies have noted a correlation between viral and bacterial infections and the accumulation of A $\beta$ peptides. Mice infected with HSV-1 [78], pseudorabies virus [79], C. pneumoniae [75] and $P$. gingivalis $[68,80]$ were found to have a significantly increased level of $A \beta_{1-42}$ in the brain. In addition, $A \beta$ expression was found to be upregulated in rats exposed to bacterial pathogens. HSV-1 has also been found to infect the hippocampus region at a greater rate; the same area found to have greater amounts of A $\beta$ plaques in AD [81]. In vitro studies observed cells co-cultured with either HSV-1, HSV-2, P. gingivalis or B. burgdoferi to have increased intracellular concentrations of A $\beta$ [80,82-89]. Furthermore, HSV-1 has been associated with the inhibition of the non-amyloidogenic pathway of APP metabolism, and the increased expression of $\beta$-secretase. This is evidenced by a 2011 study indicating the direct and frequent interaction between HSV-1 and A $\beta P P$ [90]. A $\beta$ plaques have also been identified in the brains of HIV-1-infected individuals. Autopsies performed on $162 \mathrm{HIV}$ positive 
individuals found roughly half of them to contain $A \beta$ plaques [91]. Cell culture studies observed an increase in $\mathrm{A} \beta$ production and secretion following exposure to mRNA and proteins from the HIV Nef gene [92].

It must be noted, however, that the association between infection and $\mathrm{A} \beta$ plaque formation is not consistent across all populations. For example, in the study previously mentioned by Sundar et al., younger and healthier individuals exposed to C. pneumoniae did not exhibit the same AB peptide and NFT formation as older and immunocompromised subjects [74]. Moreover, it has been observed that genetic discrepancies, especially in the APOE gene, influence one's susceptibility to HSV-1 infection and subsequent AD development. Specifically, the APOE 4 allele places individuals at a greater risk of developing HSV-1-associated AD, with a combination of APOE 4 and HSV-1 comprising $60 \%$ of all $\mathrm{AD}$ cases $[93,94]$. This finding has been recapitulated in animal studies, where mice with the APOE 4 allele display a greater viral load than mice with other allele types after HSV-1 infection [95].

\section{3. $A \beta$ as an Antimicrobial Peptide}

It is clear that a relation exists between bacterial and viral infections and $A \beta$ production rate, as described in the previous section. $A \beta$ peptides have long been thought to lack any physiological function; however, this notion has been challenged in recent years. Clinical studies have observed the depletion of $A \beta$ peptides, through anti-A $\beta$ therapies, to increase the rate of infections in some participants. Furthermore, $\mathrm{A} \beta$ plaques have been found to contain microbial and viral DNA, such as HSV-1. One study identified HSV-1 virus DNA in roughly $90 \%$ of A $\beta$ plaques [96]. In addition, $\mathrm{AD}$ brains have been associated with 5- to 10-fold increases in bacterial read compared to control brains [64]. In the presence of bacterial lipopolysaccharides, microglial cells have also been shown to upregulate $A \beta$ production [97]. From these and similar findings, it has been suggested that the pathogenesis of $\mathrm{AD}$ could be triggered by viral and/or microbial infections. These observations led to the recent development of the antimicrobial protection hypothesis for $\mathrm{AD}$, which explores the notion of $\mathrm{A} \beta$ peptides having a role in innate immunity as an AMP that aids in the entrapment and degradation of invading bacteria and viruses.

The innate immune system utilizes AMPs to target invading microorganisms, such as bacteria, viruses, fungi, and in some instances cancerous cells. Mammalian AMPs exist in three main families: defensins, histatins and cathelicidins [98]. Similar to how A $\beta$ peptides are generated through the two-step cleavage of APP, AMPs are also formed from the breakdown of larger precursor proteins. Examples of amyloid AMPs that have a role in immunity are present in the human body. Amyloidogenic major basic protein-1 (MBP-1) is implemented in eosinophils against pathogens [99]. Like A $\beta$ peptides, MBP-1 also forms aggregates, specifically at the surface of the bacteria to limit its spread. Further support of $A \beta$ peptides being AMP stems from their similarity to AMP LL-37, the only cathelicidin identified thus far in humans. Both compounds exhibit tendencies to form cytotoxic soluble oligomers and insoluble fibrils, characteristic features of tinctorial amyloid [98]. Additionally, deficiency in the latter can result in Kostmann syndrome, an immunodeficiency disorder that, if left untreated, can result in death due to infection within the first year of life [81]. High levels of LL-37 are likewise dangerous, as they has been associated with the development of plaques in atherosclerosis and other non-infectious diseases [98]. Protein analyses comparing known AMPs and A $\beta$ peptides demonstrate structural similarities between these peptides, as well sequential similarities pointing to a shared homology between $\mathrm{A} \beta$ peptides and a specific family of bacteriocins [100]. This is particularly notable as bacteriocins are traditionally synthesized by bacteria as part of an antimicrobial response to contact with closely-related strains [101]. If verified as an AMP, A $\beta$ would not be the only AMP suggested to be involved in AD. Often expressed in epithelial cells, $\beta$-defensin- 1 is significantly elevated in astrocytes of the hippocampus, the choroid plexus, and the granulovacuolar degeneration structures of AD brain samples [102].

In vitro studies suggest the ability of $A \beta$ peptides to be an AMP, and inhibit growth of a number of bacteria and viruses. In respect to the latter, $A \beta$ has been shown to have antiviral activity against 
both HSV-1 and the influenza virus A by inhibiting the infectivity of HSV-1 [82], influenza virus A [103], H3N2 [103] and H1N1 [103]. Researchers found that in mouse and human neural cell cultures, A $\beta$ peptide deposition was accelerated in response to HSV-1 and HHV6 infection, with the oligomers binding to the viruses as part of a protective entrapment mechanism [104]. A $\beta$ peptides have also been shown to have antimicrobial properties against both Gram-positive and Gram-negative bacteria, including Enterococcus faecalis, Escherichia coli, Listeria monocytogenes, Salmonella typhimurium, Staphylococcus aureus, Staphylococcus epidermidis, Streptococcus agalactiae and Streptococcus pneumoniae [30]. In a study comparing $A \beta$ peptides and LL-37, Soscia et al. found that, against eight different bacteria and viruses, $\mathrm{A} \beta$ peptides demonstrated an antimicrobial activity equivalent to, and sometimes even greater than, the known AMP LL-37. The same study also found that, when comparing the brain homogenates of $\mathrm{A} \beta$-enriched areas from both $\mathrm{AD}$ and non-AD brains, the $\mathrm{AD}$ brain samples had elevated antimicrobial and antiviral activity. These discrepancies were eliminated once the AD brain tissues were immunodepleted using anti-A $\beta$ antibodies. It is important to consider the sequence length of the $A \beta$ peptide when examining its antimicrobial capabilities, as $A \beta_{1-42}$ was shown to be capable of binding to the surface of bacteria and aggregating into clusters, whereas other peptide lengths were not [105].

Animal studies have further evidenced the important potential role that $\mathrm{A} \beta$ peptides have in protecting against infections. In a 2016 study, researchers tested A $\beta$ 's functionality as an AMP in mice and nematode models [106]. Kumar et al. found that transgenic 5XFAD mice, which constitutively express human $A \beta$ peptides, survived significantly longer than wild-type mice after the injection of Salmonella typhimurium into their brains. The 5XFAD mice were observed to have accelerated A $\beta$ deposition that closely co-localized with the bacteria, reducing their cerebral viral load compared to wild-type mice. These findings were recapitulated again in worm models, as nematodes expressing A $\beta$ were found to have increased survival following fungal infection of $C$. albicans, compared to nematodes that did not produce $\mathrm{A} \beta$ peptides. Additionally, it has been observed that impaired mice that lacked the ability to generate $A \beta$ peptides have been shown to have increased postpartum mortality, which was only reversed by maintaining a sterile environment [107]. Furthermore, APP knockout mice were also observed to have increased rates of mortality. Altogether, these studies support the notion that $\mathrm{A} \beta$ peptides are an $\mathrm{AMP}$, and an integral part of the brain's innate immune response against invading pathogens.

The mechanism by which $\mathrm{A} \beta$ peptides have been suggested to exert their antimicrobial and antiviral effect has been based on entrapment and lytic activity, as illustrated in Figure 2. Being a self-complimentary peptide containing two distinct hydrophobic and hydrophilic surfaces, A $\beta$ peptides can self-assemble into oligomers. As oligomerization continues, a fibril network is created which targets, captures and agglutinates microbes, limiting their proliferation and impact on their environment. $\mathrm{A} \beta$ peptide affinity towards microbes has been suggested to be due to its positive charge and the microbe's negatively charged membrane $[30,108,109]$. Furthermore, the ability of A $\beta$ peptides to agglutinate microbes stems from its heparin-binding activity, which is able to target carbohydrates present on the surface of microbes. Once entrapped, it is suggested that A $\beta$ peptides induce cell membrane disruption by forming cation channels. These channels cause ion dyshomeostasis and subsequent cell death. This mechanism is similar to the activity observed in AMPs such as LL-37, which assert protection through microbial agglutination and entrapment. The oligomerization activity observed with $\mathrm{A} \beta$ peptides is a common trait of AMPs, which mediates their ability to entrap and lyse pathogens while maintaining their resistance to protease activity. The entrapment of microbes and viruses can also enhance their uptake by neutrophils and macrophages. In respect to HSV-1, $\mathrm{A} \beta$ peptides have been proposed to interfere with its ability to fuse with the plasma membrane of cells, hindering its infective ability [110]. 


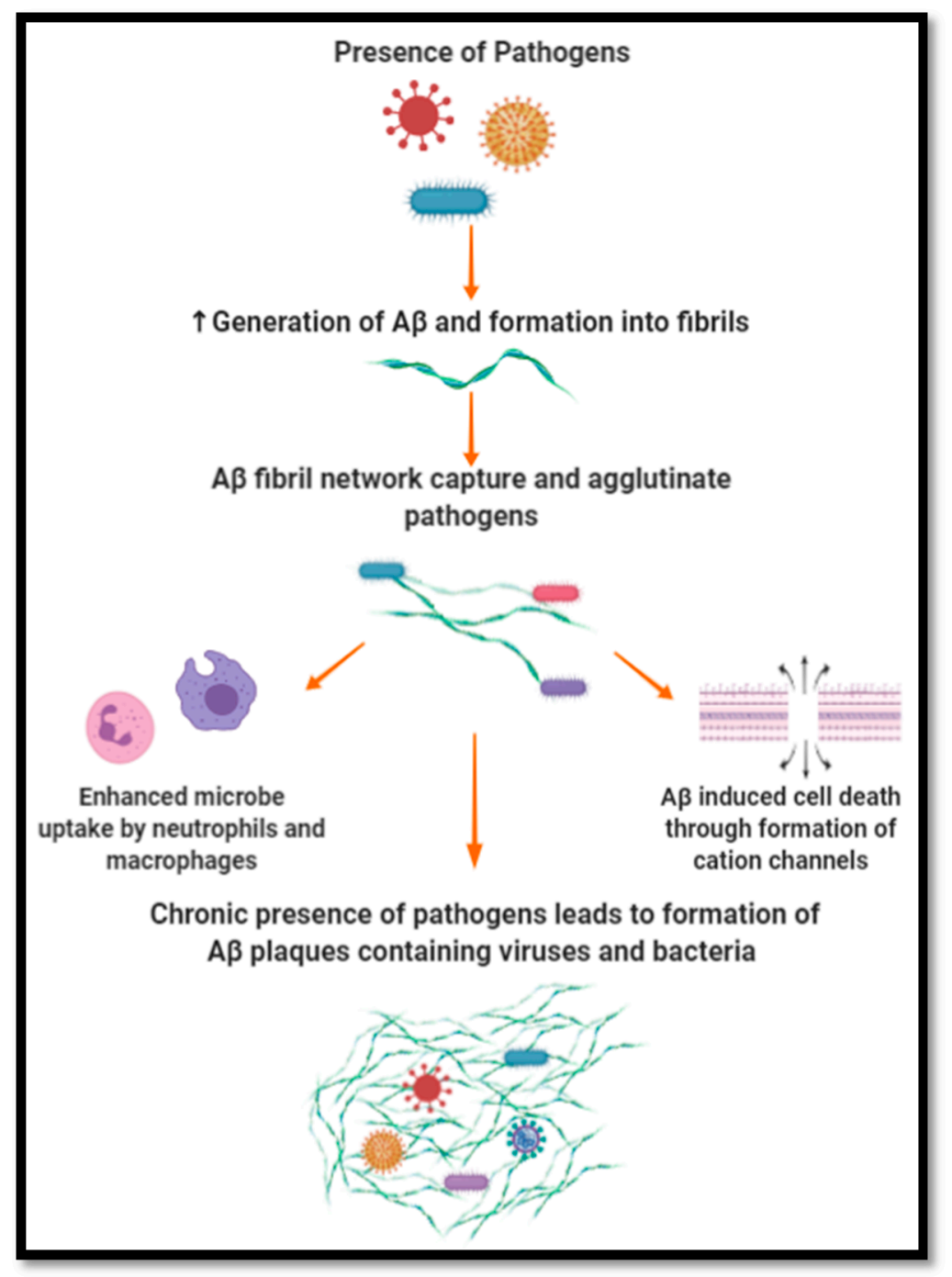

Figure 2. $A \beta$ as an antimicrobial peptide.

\section{Potential Novel Therapeutics}

In aligning with the antimicrobial hypothesis of $\mathrm{AD}$, the use of antimicrobial and antiviral therapeutics could prove to be effective in targeting the root cause of AD. It should be noted, however, that the chronic over-production of $A \beta$ peptides, which form numerous insoluble plaques, would also need to be addressed. As such, the primary aim of these drugs would be to target bacteria and viruses, but a secondary aim would be to reduce the already-present $\mathrm{A} \beta$ burden that the brain is under.

\subsection{Antiviral Drugs}

\subsubsection{Acyclovir}

Acyclovir is an antiviral drug that is used for HSV-1 infections, which has been found to be well tolerated and safe [111]. By inhibiting the virus's replication, this antiviral agent is able to reduce the viral load exhibited by HSV-1. Administration of acyclovir in HSV-1-infected cells has been found to cause a significant reduction of HSV-1 proteins, along with a reduction of roughly $28 \%$ in A $\beta$ accumulation, compared to untreated cells. The study associated this with reduced levels of $\beta$-secretase and a component of $\gamma$-secretase which metabolizes APP into A $\beta$ [112]. Acyclovir administration has also shown to prevent HSV-1-related neuronal death [113]. In relation to the cognitive impairment observed in $\mathrm{AD}$, a study by Hui et al. investigated the effects of acyclovir on $\mathrm{A} \beta$ oligomer-induced spatial 
cognitive impairments. The study found that the co-administration of acyclovir with dexamethasone attenuated impairments in spatial cognition. Furthermore, this combination reduced the levels of neuroinflammation markers such as TNF- $\alpha$ and IL-6, along with microglia activation. Interestingly, the study found these effects to only occur when acyclovir and dexamethasone were administered together [114].

\subsubsection{Penciclovir}

Penciclovir is another antiviral drug that targets HSV-1 DNA replication by blocking chain elongation. Cell cultures infected with HSV- 1 displayed a reduction of virus and A $\beta$ accumulation when penciclovir was administered. This was paralleled with a reduction in $\beta$-secretase and a component of $\gamma$-secretase [112].

\subsubsection{Foscarnet}

Foscarnet has been tested for its ability to reduce HSV-1 levels in vitro. A study found it was able to reduce $A \beta$ accumulation, although only at higher doses. It was also unable to significantly reduce virus levels. Furthermore, foscarnet was not as effective as acyclovir or penciclovir, and hence currently is not seen as the optimal antiviral drug available for AD [112].

\subsubsection{Valacyclovir}

Valacyclovir, an antiviral medication used in HSV-1 and HSV-2 infections, has been determined to positively impact cognition by improving visual object learning, verbal memory and working memory in patients with schizophrenia [115]. Due to its effects on working memory, its effectiveness against HSV-1 and HSV-2, and its generally safe consumption, valacyclovir has been suggested as a potential therapeutic for AD. A clinical study is currently underway in which patients that both have mild AD and tested positive for HSV-1 or HSV-2 will receive valacyclovir. The aim of the study is to determine the impact of this treatment on cognition and the accumulation of amyloid and tau [116].

\subsubsection{Bay $57-1293$}

Numerous studies have determined the antiviral agent Bay 57-1293 to be effective in combating HSV-1 [117-121]. By targeting the helicase-primase complex, Bay 57-1293 can inhibit viral DNA replication, and has been found to be more potent than acyclovir. The severity and frequency of recurring HSV was also found to be reduced by use of this drug [121]. Furthermore, it was able to decrease levels of $A \beta$ and reduce P-tau production in Vero cells infected with HSV-1 [117].

\subsubsection{Biflavonoids}

Our lab has investigated the use of bioflavonoids, including ginkgetin, isoginkgetin and ginkgolic acid, derived from the leaves of Ginkgo biloba. The antiviral capabilities of these compounds has been well established in previous studies [122-126]. Hayashi et al. determined ginkgetin to successfully inhibit the viral replication of HSV-1, HSV-2 and the human cytomegalovirus, while also suppressing viral protein synthesis [122]. Additionally, a study by Miki et al. found ginkgetin to have anti-influenza virus activity [123]. Ginkgetin has been studied for use in AD by Zeng et al., who administered the drug to APP/PS1 transgenic mice. They observed a significant reduction in A $\beta$ plaques and an improvement in inflammation [127]. Borenstein et al. have demonstrated the ability of ginkgolic acid to limit virus infectivity by inhibiting its fusion. The study found ginkgolic acid to be successful in inhibiting HSV-1, human cytomegalovirus and zika virus. Furthermore, it was effective in inhibiting viral protein synthesis and genome replication, in HSV-1 and human cytomegalovirus, respectively [124]. Ginkgolic acid has also demonstrated antimicrobial properties, specifically against E. coli and Staphlylococcus aureus [125]. Isoginkgetin has been shown to provide neuroprotection against the cytotoxic effects of excessive $\mathrm{A} \beta$ accumulation $[128,129]$, while also having anti-microbial 
and anti-fungal activity [126]. Our lab's preliminary work in testing these three compounds in AD determined their effectiveness in reducing $A \beta$ load in vitro, further supporting their therapeutic potential in $\mathrm{AD}$.

\subsection{Antimicrobial Drugs}

\subsubsection{Doxycycline}

Doxycycline is a tetracycline antibiotic that has been studied for its therapeutic efficacy in AD models. Contrary to other tetracyclines, doxycycline has been determined to be safe and is able to penetrate the BBB [130], allowing it to exert its effect directly in the CNS. In vivo models, in which doxycycline was administered to mice, observed its accumulation in amyloid deposits, including $\mathrm{A} \beta$ plaques [131]. With respect to the production and formation of $A \beta$ oligomers, it was observed that although doxycycline administration in transgenic mice did not cause a shift in A $\beta$ monomers, there was a significant reduction in $A \beta$ 18-mer levels when compared to control [132]. The same study also observed a significant memory recovery in animals that received treatment; however, there was no reduction in $A \beta$ plaque size [132]. The paper suggested this was possibly due to the short two-month period of the study, as a previous three-month study found plaque size to be significantly reduced [132]. In respect to neuroinflammation, a reduction in microglia activation has also been associated with doxycycline administration [132]. A drosophila model, which administered doxycycline to $A \beta_{1-42}$-expressing flies, observed that the treated group's locomotor deficits developed slower than the control group. The same study also observed doxycycline administration to be associated with reduced $A \beta$ fibrilization, suggesting the production of smaller amyloid structures [133]. Another study associated doxycycline with the destabilization of $A \beta$ fibrils [134]. Clinical trials, however, were not as successful. One study, which administered doxycycline and rifampicin, observed improvements in cognitive function, as assessed by the Standardized Alzheimer's Disease Assessment Scale-Cognitive Subscale (SADAScog) score [135]. However, a second study did not find any improvements in the cognition or function of patients with mild to moderate AD with doxycycline/rifampicin administration [136]. Further investigations would be needed to understand why the benefits seen in murine models do not translate into clinical trials.

\subsubsection{Propranolol}

Propranolol hydrochloride, an antihypertensive drug shown to have antimicrobial properties [137], has also been found to impact $A \beta$ production. Cortico-hippocampal neuronal cultures treated with this drug manifested reduced levels of $A \beta$ production. Furthermore, the one-month treatment of $\mathrm{Tg} 2576$ mice resulted in roughly a $40 \%$ reduction of $A \beta_{1-40}$ and $A \beta_{1-42}$ levels in the brain. When administered over a period of 6 months, $A \beta$ peptide levels were still reduced in the brain; however, no improvement in spatial memory function was observed [138].

\subsubsection{Rifampicin}

Rifampicin is an antibiotic derived from Nocardia mediterranei, which has been investigated for use in neurodegenerative diseases such as Parkinson's and AD [139,140]. Rifampicin has been found to provide neuroprotection through its anti-oxidant and anti-inflammatory properties [139,141]. Furthermore, in vitro studies found that its administration improved neuronal survival and reduced microglial activation [141]. Studies by Tomiyama et al. found rifampicin to protect neurons from cytotoxicity by scavenging free radicals $[142,143]$. In relation to the antimicrobial hypothesis, rifampicin has been previously studied for use in bacterial cerebral infections [144]. As rifampicin is able to cross the BBB [144], it can exert its antimicrobial effect directly in the brain. In the presence of rifampicin, a reduction of $A \beta$ fibril formation [142] has been observed in addition to augmented $A \beta$ clearance [145]. A study by Umeda et al., in which rifampicin was administered to APPOSK mice, found the treatment to reduce $A \beta$ accumulation, provide synaptic protection, and reduce microglial activation [146]. 
Clinical studies exploring the impact of rifampicin on cognitive function have also been investigated, as mentioned in previous sections. Even with its many benefits, the oral intake of rifampicin has also been associated with liver injury in humans. To circumvent this limitation, administering rifampicin intranasally or subcutaneously has been suggested [147]. These routes of rifampicin administration have been shown to be more effective in improving memory than oral administration [147].

\subsubsection{Gingipain Inhibitors}

The use of gingipain inhibitors in $\mathrm{AD}$ is another approach that has been taken to alleviate the negative impact of the disease. Gingipains are virulence factors that are produced by P. gingivalis [148]. They are made up of a group of cysteine proteinases, specifically arginin-gingipain A, arginine-gingipain B, and lysign-gingipain $[148,149]$. Given the key role gingipains play in host colonization [148] and the inactivation of host defenses [150-152], they are essential for the survival and pathogenicity of $P$. gingivalis. Regarding $\mathrm{A} \beta_{1-42}$ peptide production, $P$. gingivalis infection was found to increase $A \beta_{1-42}$ levels. Furthermore, incubating $P$. gingivalis with $A \beta_{1-42}$ peptides led to a significant increase in $P$. gingivalis death. These two findings further support the antimicrobial hypothesis for $A \beta$ peptides [153]. Gingipain inhibitors, such as COR286, COR271 and COR388, have been found to be effective in inducing $P$. gingivalis death and reducing the bacterial load in the brain, more so than other antibiotics, such as moxifloxacin [153,154]. In addition, COR271 was found to provide some level of neuroprotection as well [153]. The administration of gingipain inhibitors has also been associated with a decrease in host $\mathrm{A} \beta_{1-42}$ response to P. gingivalis infection [68].

\subsection{Limitations}

Even with the benefits associated with the antimicrobial and antiviral drugs listed above, insights into their mechanism of action and their impact on $A \beta$ peptide levels are needed. A greater understanding as to whether their administration indirectly reduces the presence of $A \beta$ peptides by reducing the viral/bacterial load on the brain, or if they act directly in reducing $\mathrm{A} \beta$ peptides level, is needed. If it is the latter, and the antimicrobial hypothesis for $\mathrm{A} \beta$ peptides holds true, their efficacy might not be as positive as hoped. In addition, it is important that the chosen antimicrobial or antiviral drug does not have any adverse effects that could take away from its benefits. For example, cefepime is an antibiotic that has shown to be able to cross the blood-brain barrier and cause neurotoxic symptoms [154].

\section{Conclusions and Future Directions}

The findings of the numerous studies highlighted in this review present a clear indication of the role bacteria and viruses can have in AD development. Even with this conclusion, it is clear that a specific bacteria or virus alone is not responsible for $\mathrm{AD}$ development, as no specific bacteria or virus has been identified to be universally present in all AD brains. Rather, a number of viruses and bacteria could exacerbate the progression of neurodegenerative diseases, either independently or along with other pathogens. By exploring the presence of multiple viruses/bacteria in AD brains, future investigations can give insights into which microorganisms are most present, and whether all AD brains have both a detected and increased level of selected bacteria/virus. The use of antiviral and antimicrobial drugs early on, while the patient is still in the presymptomatic phase of $A D$, could have potential effectiveness in targeting the root cause of $\mathrm{AD}$ pathogenesis and alleviating the viral/microbial load on the brain. Further investigations into their use in AD would give greater insight regarding their efficacy and limitations.

Author Contributions: U.H.I. and G.M.P. conceptualized the manuscript. U.H.I. and E.Z. wrote the manuscript. U.H.I., E.Z., and G.M.P. reviewed and edited the manuscript. All authors have read and agree to the published version of the manuscript. 
Funding: This study was supported by the Altschul Foundation and in part by grant number P50 AT008661-01 from the NCCIH and ODS. We acknowledge that the contents of this review do not represent the views of the $\mathrm{NCCIH}$, the ODS, the NIH, or the United States Government.

Acknowledgments: Figures were made using BioRender.

Conflicts of Interest: The authors declare no conflict of interest.

\section{Abbreviations}

$\begin{array}{ll}\text { AD } & \text { Alzheimer's Disease } \\ \text { A } \beta & \text { amyloid- } \beta \\ \text { AMP } & \text { antimicrobial peptide } \\ \text { APP } & \text { amyloid precursor proteins } \\ \text { BACE1 } & \text { B-site ABPP cleaving enzyme } \\ \text { BBB } & \text { blood brain barrier } \\ \text { CNS } & \text { central nervous system } \\ \text { HSV-1 } & \text { herpes simplex virus-1 } \\ \text { MBP-1 } & \text { major basic protein-1 } \\ \text { NFTS } & \text { neurofibrillary tangles }\end{array}$

\section{References}

1. Alzheimer's Association. 2019 Alzheimer's Disease Facts and Figures. Alzheimer's Dement. 2019, 15, 321-387. [CrossRef]

2. Soria Lopez, J.A.; Gonzalez, H.M.; Leger, G.C. Alzheimer's disease. Handb. Clin. Neurol. 2019, 167, $231-255$. [CrossRef] [PubMed]

3. Hardy, J.; Allsop, D. Amyloid deposition as the central event in the aetiology of Alzheimer's disease. Trends Pharmacol. Sci. 1991, 12, 383-388. [CrossRef]

4. Hardy, J.A.; Higgins, G.A. Alzheimer's disease: The amyloid cascade hypothesis. Science 1992, 256, $184-185$. [CrossRef]

5. Surgucheva, I.; Newell, K.L.; Burns, J.; Surguchov, A. New $\alpha$ - and $\gamma$-synuclein immunopathological lesions in human brain. Acta Neuropathol. Commun. 2014, 2, 132. [CrossRef] [PubMed]

6. Gomez-Isla, T.; Hollister, R.; West, H.; Mui, S.; Growdon, J.H.; Petersen, R.C.; Parisi, J.E.; Hyman, B.T. Neuronal loss correlates with but exceeds neurofibrillary tangles in Alzheimer's disease. Ann. Neurol. 1997, 41, 17-24. [CrossRef]

7. Tetz, G.; Pinho, M.; Pritzkow, S.; Mendez, N.; Soto, C.; Tetz, V. Bacterial DNA promotes Tau aggregation. Sci. Rep. 2020, 10, 2369. [CrossRef]

8. Nelson, P.T.; Alafuzoff, I.; Bigio, E.H.; Bouras, C.; Braak, H.; Cairns, N.J.; Castellani, R.J.; Crain, B.J.; Davies, P.; Del Tredici, K.; et al. Correlation of Alzheimer disease neuropathologic changes with cognitive status: A review of the literature. J. Neuropathol. Exp. Neurol. 2012, 71, 362-381. [CrossRef]

9. Giacobini, E.; Gold, G. Alzheimer disease therapy-moving from amyloid- $\beta$ to tau. Nat. Rev. Neurol. 2013, 9 , 677-686. [CrossRef]

10. Sato, C.; Barthelemy, N.R.; Mawuenyega, K.G.; Patterson, B.W.; Gordon, B.A.; Jockel-Balsarotti, J.; Sullivan, M.; Crisp, M.J.; Kasten, T.; Kirmess, K.M.; et al. Tau Kinetics in Neurons and the Human Central Nervous System. Neuron 2018, 97, 1284-1298. [CrossRef]

11. Hardy, J.; Selkoe, D.J. The amyloid hypothesis of Alzheimer's disease: Progress and problems on the road to therapeutics. Science 2002, 297, 353-356. [CrossRef] [PubMed]

12. Cai, Z.; Hussain, M.D.; Yan, L.J. Microglia, neuroinflammation, and beta-amyloid protein in Alzheimer's disease. Int. J. Neurosci. 2014, 124, 307-321. [CrossRef] [PubMed]

13. Panza, F.; Lozupone, M.; Logroscino, G.; Imbimbo, B.P. A critical appraisal of amyloid-beta-targeting therapies for Alzheimer disease. Nat. Rev. Neurol. 2019, 15, 73-88. [CrossRef]

14. Arbor, S.C.; LaFontaine, M.; Cumbay, M. Amyloid-beta Alzheimer targets-protein processing, lipid rafts, and amyloid-beta pores. Yale J. Biol. Med. 2016, 89, 5-21. [PubMed]

15. Murphy, M.P.; LeVine, H., 3rd. Alzheimer's disease and the amyloid-beta peptide. J. Alzheimer's Dis. 2010, 19, 311-323. [CrossRef] [PubMed] 
16. Nunan, J.; Small, D.H. Regulation of APP cleavage by alpha-, beta- and gamma-secretases. FEBS Lett. 2000, 483, 6-10. [CrossRef]

17. Chen, G.F.; Xu, T.H.; Yan, Y.; Zhou, Y.R.; Jiang, Y.; Melcher, K.; Xu, H.E. Amyloid beta: Structure, biology and structure-based therapeutic development. Acta Pharmacol. Sin. 2017, 38, 1205-1235. [CrossRef]

18. Gravina, S.A.; Ho, L.; Eckman, C.B.; Long, K.E.; Otvos, L., Jr.; Younkin, L.H.; Suzuki, N.; Younkin, S.G. Amyloid beta protein (A beta) in Alzheimer's disease brain. Biochemical and immunocytochemical analysis with antibodies specific for forms ending at A beta 40 or A beta 42(43). J. Biol. Chem. 1995, 270, 7013-7016. [CrossRef]

19. McGowan, E.; Pickford, F.; Kim, J.; Onstead, L.; Eriksen, J.; Yu, C.; Skipper, L.; Murphy, M.P.; Beard, J.; Das, P.; et al. Abeta42 is essential for parenchymal and vascular amyloid deposition in mice. Neuron 2005, 47, 191-199. [CrossRef]

20. Kim, J.; Onstead, L.; Randle, S.; Price, R.; Smithson, L.; Zwizinski, C.; Dickson, D.W.; Golde, T.; McGowan, E. Abeta40 inhibits amyloid deposition in vivo. J. Neurosci. 2007, 27, 627-633. [CrossRef]

21. Orgogozo, J.M.; Gilman, S.; Dartigues, J.F.; Laurent, B.; Puel, M.; Kirby, L.C.; Jouanny, P.; Dubois, B.; Eisner, L.; Flitman, S.; et al. Subacute meningoencephalitis in a subset of patients with AD after Abeta42 immunization. Neurology 2003, 61, 46-54. [CrossRef] [PubMed]

22. Gilman, S.; Koller, M.; Black, R.S.; Jenkins, L.; Griffith, S.G.; Fox, N.C.; Eisner, L.; Kirby, L.; Rovira, M.B.; Forette, F.; et al. Clinical effects of Abeta immunization (AN1792) in patients with AD in an interrupted trial. Neurology 2005, 64, 1553-1562. [CrossRef] [PubMed]

23. Weggen, S.; Eriksen, J.L.; Das, P.; Sagi, S.A.; Wang, R.; Pietrzik, C.U.; Findlay, K.A.; Smith, T.E.; Murphy, M.P.; Bulter, T.; et al. A subset of NSAIDs lower amyloidogenic Abeta42 independently of cyclooxygenase activity. Nature 2001, 414, 212-216. [CrossRef] [PubMed]

24. Kukar, T.L.; Ladd, T.B.; Bann, M.A.; Fraering, P.C.; Narlawar, R.; Maharvi, G.M.; Healy, B.; Chapman, R.; Welzel, A.T.; Price, R.W.; et al. Substrate-targeting gamma-secretase modulators. Nature 2008, 453, 925-929. [CrossRef] [PubMed]

25. Green, R.C.; Schneider, L.S.; Amato, D.A.; Beelen, A.P.; Wilcock, G.; Swabb, E.A.; Zavitz, K.H. Effect of tarenflurbil on cognitive decline and activities of daily living in patients with mild Alzheimer disease: A randomized controlled trial. JAMA 2009, 302, 2557-2564. [CrossRef]

26. Doody, R.S.; Raman, R.; Farlow, M.; Iwatsubo, T.; Vellas, B.; Joffe, S.; Kieburtz, K.; He, F.; Sun, X.; Thomas, R.G.; et al. A phase 3 trial of semagacestat for treatment of Alzheimer's disease. N. Engl. J. Med. 2013, 369, 341-350. [CrossRef]

27. McLaurin, J.; Golomb, R.; Jurewicz, A.; Antel, J.P.; Fraser, P.E. Inositol stereoisomers stabilize an oligomeric aggregate of Alzheimer amyloid beta peptide and inhibit abeta -induced toxicity. J. Biol. Chem. 2000, 275, 18495-18502. [CrossRef]

28. Salloway, S.; Sperling, R.; Keren, R.; Porsteinsson, A.P.; van Dyck, C.H.; Tariot, P.N.; Gilman, S.; Arnold, D.; Abushakra, S.; Hernandez, C.; et al. A phase 2 randomized trial of ELND005, scyllo-inositol, in mild to moderate Alzheimer disease. Neurology 2011, 77, 1253-1262. [CrossRef]

29. Therapeutics-Elenbecestat. Available online: https://www.alzforum.org/therapeutics/elenbecestat (accessed on 7 May 2020).

30. Gosztyla, M.L.; Brothers, H.M.; Robinson, S.R. Alzheimer's Amyloid- $\beta$ is an Antimicrobial Peptide: A Review of the Evidence. J. Alzheimer's Dis. 2018, 62, 1495-1506. [CrossRef]

31. Caselli, R.J.; Reiman, E.M. Characterizing the preclinical stages of Alzheimer's disease and the prospect of presymptomatic intervention. J. Alzheimer's Dis. 2013, 33, S405-S416. [CrossRef]

32. Villemagne, V.L.; Burnham, S.; Bourgeat, P.; Brown, B.; Ellis, K.A.; Salvado, O.; Szoeke, C.; Macaulay, S.L.; Martins, R.; Maruff, P.; et al. Amyloid $\beta$ deposition, neurodegeneration, and cognitive decline in sporadic Alzheimer's disease: A prospective cohort study. Lancet Neurol. 2013, 12, 357-367. [CrossRef]

33. Hampel, H.; O’Bryant, S.E.; Molinuevo, J.L.; Zetterberg, H.; Masters, C.L.; Lista, S.; Kiddle, S.J.; Batrla, R.; Blennow, K. Blood-based biomarkers for Alzheimer disease: Mapping the road to the clinic. Nat. Rev. Neurol. 2018, 14, 639-652. [CrossRef] [PubMed]

34. Bousiges, O.; Cretin, B.; Lavaux, T.; Philippi, N.; Jung, B.; Hezard, S.; Heitz, C.; Demuynck, C.; Gabel, A.; Martin-Hunyadi, C; ; et al. Diagnostic Value of Cerebrospinal Fluid Biomarkers (Phospho-Tau181, total-Tau, A $\beta 42$, and A 340 ) in Prodromal Stage of Alzheimer's Disease and Dementia with Lewy Bodies. J. Alzheimer's Dis. 2016, 51, 1069-1083. [CrossRef] [PubMed] 
35. Janelidze, S.; Stomrud, E.; Palmqvist, S.; Zetterberg, H.; van Westen, D.; Jeromin, A.; Song, L.; Hanlon, D.; Tan Hehir, C.A.; Baker, D.; et al. Plasma $\beta$-amyloid in Alzheimer's disease and vascular disease. Sci. Rep. 2016, 6, 26801. [CrossRef]

36. Weston, P.S.J.; Poole, T.; Ryan, N.S.; Nair, A.; Liang, Y.; Macpherson, K.; Druyeh, R.; Malone, I.B.; Ahsan, R.L.; Pemberton, H.; et al. Serum neurofilament light in familial Alzheimer disease: A marker of early neurodegeneration. Neurology 2017, 89, 2167-2175. [CrossRef] [PubMed]

37. Salvadores, N.; Shahnawaz, M.; Scarpini, E.; Tagliavini, F.; Soto, C. Detection of misfolded A $\beta$ oligomers for sensitive biochemical diagnosis of Alzheimer's disease. Cell Rep. 2014, 7, 261-268. [CrossRef] [PubMed]

38. Kraus, A.; Saijo, E.; Metrick, M.A., 2nd; Newell, K.; Sigurdson, C.J.; Zanusso, G.; Ghetti, B.; Caughey, B. Seeding selectivity and ultrasensitive detection of tau aggregate conformers of Alzheimer disease. Acta Neuropathol. 2019, 137, 585-598. [CrossRef]

39. Kinney, J.W.; Bemiller, S.M.; Murtishaw, A.S.; Leisgang, A.M.; Salazar, A.M.; Lamb, B.T. Inflammation as a central mechanism in Alzheimer's disease. Alzheimer's Dement. 2018, 4, 575-590. [CrossRef]

40. DiSabato, D.J.; Quan, N.; Godbout, J.P. Neuroinflammation: The devil is in the details. J. Neurochem. 2016, 139, 136-153. [CrossRef] [PubMed]

41. Skaper, S.D.; Facci, L.; Zusso, M.; Giusti, P. An Inflammation-Centric View of Neurological Disease: Beyond the Neuron. Front. Cell Neurosci. 2018, 12, 72. [CrossRef]

42. Vinayagam, R.; Bhuvaneswarri, J.; Paddmanabhan, P.; Manisundar, N. Alziemer's Disease and Periodontal Disease Bidirectional Interrelationships. Biosci. Biotechnol. Res. Asia 2014, 11, 259-261. [CrossRef]

43. Klein, R.S.; Garber, C.; Howard, N. Infectious immunity in the central nervous system and brain function. Nat. Immunol. 2017, 18, 132-141. [CrossRef]

44. Hensley, K. Neuroinflammation in Alzheimer's disease: Mechanisms, pathologic consequences, and potential for therapeutic manipulation. J. Alzheimer's Dis. 2010, 21, 1-14. [CrossRef] [PubMed]

45. De Chiara, G.; Marcocci, M.E.; Sgarbanti, R.; Civitelli, L.; Ripoli, C.; Piacentini, R.; Garaci, E.; Grassi, C.; Palamara, A.T. Infectious agents and neurodegeneration. Mol. Neurobiol. 2012, 46, 614-638. [CrossRef] [PubMed]

46. Fulop, T.; Itzhaki, R.F.; Balin, B.J.; Miklossy, J.; Barron, A.E. Role of Microbes in the Development of Alzheimer's Disease: State of the Art-An International Symposium Presented at the 2017 IAGG Congress in San Francisco. Front. Genet. 2018, 9, 362. [CrossRef] [PubMed]

47. Itzhaki, R.F.; Lathe, R.; Balin, B.J.; Ball, M.J.; Bearer, E.L.; Braak, H.; Bullido, M.J.; Carter, C.; Clerici, M.; Cosby, S.L.; et al. Microbes and Alzheimer's Disease. J. Alzheimer's Dis. 2016, 51, 979-984. [CrossRef] [PubMed]

48. Miklossy, J. Historic evidence to support a causal relationship between spirochetal infections and Alzheimer's disease. Front. Aging Neurosci. 2015, 7, 46. [CrossRef]

49. Maheshwari, P.; Eslick, G.D. Bacterial infection and Alzheimer's disease: A meta-analysis. J. Alzheimer's Dis. 2015, 43, 957-966. [CrossRef]

50. Ashraf, G.M.; Tarasov, V.V.; Makhmutova, A.; Chubarev, V.N.; Avila-Rodriguez, M.; Bachurin, S.O.; Aliev, G. The Possibility of an Infectious Etiology of Alzheimer Disease. Mol. Neurobiol. 2019, 56, 4479-4491. [CrossRef]

51. Murphy, J.V.; Yunis, E.J. Encephalopathy following measles infection in children with chronic illness. J. Pediatrics 1976, 88, 937-942. [CrossRef]

52. Dobson, C.B.; Itzhaki, R.F. Herpes simplex virus type 1 and Alzheimer's disease. Neurobiol. Aging 1999, 20, 457-465. [CrossRef]

53. Balin, B.J.; Gerard, H.C.; Arking, E.J.; Appelt, D.M.; Branigan, P.J.; Abrams, J.T.; Whittum-Hudson, J.A.; Hudson, A.P. Identification and localization of Chlamydia pneumoniae in the Alzheimer's brain. Med. Microbiol. Immunol. 1998, 187, 23-42. [CrossRef] [PubMed]

54. Lurain, N.S.; Hanson, B.A.; Martinson, J.; Leurgans, S.E.; Landay, A.L.; Bennett, D.A.; Schneider, J.A. Virological and immunological characteristics of human cytomegalovirus infection associated with Alzheimer disease. J. Infect. Dis. 2013, 208, 564-572. [CrossRef] [PubMed]

55. Lovheim, H.; Olsson, J.; Weidung, B.; Johansson, A.; Eriksson, S.; Hallmans, G.; Elgh, F. Interaction between Cytomegalovirus and Herpes Simplex Virus Type 1 Associated with the Risk of Alzheimer's Disease Development. J. Alzheimer's Dis. 2018, 61, 939-945. [CrossRef] [PubMed] 
56. Linard, M.; Letenneur, L.; Garrigue, I.; Doize, A.; Dartigues, J.F.; Helmer, C. Interaction between APOE4 and herpes simplex virus type 1 in Alzheimer's disease. Alzheimer's Dement. J. Alzheimer's Assoc. 2020, 16, 200-208. [CrossRef]

57. De Chiara, G.; Piacentini, R.; Fabiani, M.; Mastrodonato, A.; Marcocci, M.E.; Limongi, D.; Napoletani, G.; Protto, V.; Coluccio, P.; Celestino, I.; et al. Recurrent herpes simplex virus-1 infection induces hallmarks of neurodegeneration and cognitive deficits in mice. PLoS Pathog. 2019, 15, e1007617. [CrossRef]

58. Wozniak, M.A.; Shipley, S.J.; Combrinck, M.; Wilcock, G.K.; Itzhaki, R.F. Productive herpes simplex virus in brain of elderly normal subjects and Alzheimer's disease patients. J. Med. Virol. 2005, 75, 300-306. [CrossRef]

59. Jamieson, G.A.; Maitland, N.J.; Wilcock, G.K.; Craske, J.; Itzhaki, R.F. Latent herpes simplex virus type 1 in normal and Alzheimer's disease brains. J. Med. Virol. 1991, 33, 224-227. [CrossRef]

60. Carbone, I.; Lazzarotto, T.; Ianni, M.; Porcellini, E.; Forti, P.; Masliah, E.; Gabrielli, L.; Licastro, F. Herpes virus in Alzheimer's disease: Relation to progression of the disease. Neurobiol. Aging 2014, 35, 122-129. [CrossRef]

61. Readhead, B.; Haure-Mirande, J.V.; Funk, C.C.; Richards, M.A.; Shannon, P.; Haroutunian, V.; Sano, M.; Liang, W.S.; Beckmann, N.D.; Price, N.D.; et al. Multiscale Analysis of Independent Alzheimer's Cohorts Finds Disruption of Molecular, Genetic, and Clinical Networks by Human Herpesvirus. Neuron 2018, 99, 64-82. [CrossRef]

62. Westfall, S.; Dinh, D.M.; Pasinetti, G.M. Investigation of Potential Brain Microbiome in Alzheimer's Disease: Implications of Study Bias. J. Alzheimer's Dis. 2020, 75, 559-570. [CrossRef]

63. Branton, W.G.; Lu, J.Q.; Surette, M.G.; Holt, R.A.; Lind, J.; Laman, J.D.; Power, C. Brain microbiota disruption within inflammatory demyelinating lesions in multiple sclerosis. Sci. Rep. 2016, 6, 37344. [CrossRef] [PubMed]

64. Emery, D.C.; Shoemark, D.K.; Batstone, T.E.; Waterfall, C.M.; Coghill, J.A.; Cerajewska, T.L.; Davies, M.; West, N.X.; Allen, S.J. 16S rRNA Next Generation Sequencing Analysis Shows Bacteria in Alzheimer's Post-Mortem Brain. Front. Aging Neurosci. 2017, 9, 195. [CrossRef]

65. Zhan, X.; Stamova, B.; Jin, L.W.; DeCarli, C.; Phinney, B.; Sharp, F.R. Gram-negative bacterial molecules associate with Alzheimer disease pathology. Neurology 2016, 87, 2324-2332. [CrossRef] [PubMed]

66. Zhan, X.; Stamova, B.; Sharp, F.R. Lipopolysaccharide Associates with Amyloid Plaques, Neurons and Oligodendrocytes in Alzheimer's Disease Brain: A Review. Front. Aging Neurosci. 2018, 10, 42. [CrossRef] [PubMed]

67. Miklossy, J.; Khalili, K.; Gern, L.; Ericson, R.L.; Darekar, P.; Bolle, L.; Hurlimann, J.; Paster, B.J. Borrelia burgdorferi persists in the brain in chronic lyme neuroborreliosis and may be associated with Alzheimer disease. J. Alzheimer's Dis. 2004, 6, 639-649. [CrossRef]

68. Dominy, S.S.; Lynch, C.; Ermini, F.; Benedyk, M.; Marczyk, A.; Konradi, A.; Nguyen, M.; Haditsch, U.; Raha, D.; Griffin, C.; et al. Porphyromonas gingivalis in Alzheimer's disease brains: Evidence for disease causation and treatment with small-molecule inhibitors. Sci. Adv. 2019, 5. [CrossRef]

69. Alonso, R.; Pisa, D.; Marina, A.I.; Morato, E.; Rábano, A.; Carrasco, L. Fungal infection in patients with Alzheimer's disease. J. Alzheimer's Dis. 2014, 41, 301-311. [CrossRef]

70. Pisa, D.; Alonso, R.; Rábano, A.; Rodal, I.; Carrasco, L. Different Brain Regions are Infected with Fungi in Alzheimer's Disease. Sci. Rep. 2015, 5, 15015. [CrossRef]

71. Romagnoli, M.; Porcellini, E.; Carbone, I.; Veerhuis, R.; Licastro, F. Impaired Innate Immunity Mechanisms in the Brain of Alzheimer's Disease. Int. J. Mol. Sci. 2020, 21, 1126. [CrossRef]

72. Rey, N.L.; Wesson, D.W.; Brundin, P. The olfactory bulb as the entry site for prion-like propagation in neurodegenerative diseases. Neurobiol. Dis. 2018, 109, 226-248. [CrossRef]

73. Hammond, C.J.; Hallock, L.R.; Howanski, R.J.; Appelt, D.M.; Little, C.S.; Balin, B.J. Immunohistological detection of Chlamydia pneumoniae in the Alzheimer's disease brain. BMC Neurosci. 2010, 11, 121. [CrossRef] [PubMed]

74. Sundar, S.; Battistoni, C.; McNulty, R.; Morales, F.; Gorky, J.; Foley, H.; Dhurjati, P. An agent-based model to investigate microbial initiation of Alzheimer's via the olfactory system. Theor. Biol. Med. Model. 2020, 17, 5. [CrossRef] [PubMed]

75. Little, C.S.; Hammond, C.J.; MacIntyre, A.; Balin, B.J.; Appelt, D.M. Chlamydia pneumoniae induces Alzheimer-like amyloid plaques in brains of BALB/c mice. Neurobiol. Aging 2004, 25, 419-429. [CrossRef] 
76. Cappellini, C.A.C.; Ahmad, B.; Williams, K.G.; Zoga, J.; Hingley, S.T. Chlamydia Pneumoniae Infection of Neuronal Cells Induces Changes in Calcium-Associated Gene Expression Consistent with Alzheimer's Disease. Available online: https://digitalcommons.pcom.edu/posters/6 (accessed on 22 May 2020).

77. Tetz, G.; Tetz, V. Prion-like Domains in Eukaryotic Viruses. Sci. Rep. 2018, 8, 8931. [CrossRef]

78. Wozniak, M.A.; Itzhaki, R.F.; Shipley, S.J.; Dobson, C.B. Herpes simplex virus infection causes cellular beta-amyloid accumulation and secretase upregulation. Neurosci. Lett. 2007, 429, 95-100. [CrossRef]

79. Tanaka, S.; Nagashima, H. Establishment of an Alzheimer's disease model with latent herpesvirus infection using PS2 and Tg2576 double transgenic mice. Exp. Anim. 2018, 67, 185-192. [CrossRef]

80. Ishida, N.; Ishihara, Y.; Ishida, K.; Tada, H.; Funaki-Kato, Y.; Hagiwara, M.; Ferdous, T.; Abdullah, M.; Mitani, A.; Michikawa, M.; et al. Periodontitis induced by bacterial infection exacerbates features of Alzheimer's disease in transgenic mice. NPJ Aging Mech. Dis. 2017, 3, 15. [CrossRef]

81. Moir, R.D.; Lathe, R.; Tanzi, R.E. The antimicrobial protection hypothesis of Alzheimer's disease. Alzheimer's Dement. J. Alzheimer's Assoc. 2018, 14, 1602-1614. [CrossRef]

82. Bourgade, K.; Le Page, A.; Bocti, C.; Witkowski, J.M.; Dupuis, G.; Frost, E.H.; Fulop, T., Jr. Protective Effect of Amyloid-beta Peptides Against Herpes Simplex Virus-1 Infection in a Neuronal Cell Culture Model. J. Alzheimer's Dis. 2016, 50, 1227-1241. [CrossRef]

83. De Chiara, G.; Marcocci, M.E.; Civitelli, L.; Argnani, R.; Piacentini, R.; Ripoli, C.; Manservigi, R.; Grassi, C.; Garaci, E.; Palamara, A.T. APP processing induced by herpes simplex virus type 1 (HSV-1) yields several APP fragments in human and rat neuronal cells. PLoS ONE 2010, 5, e13989. [CrossRef]

84. Santana, S.; Recuero, M.; Bullido, M.J.; Valdivieso, F.; Aldudo, J. Herpes simplex virus type I induces the accumulation of intracellular beta-amyloid in autophagic compartments and the inhibition of the non-amyloidogenic pathway in human neuroblastoma cells. Neurobiol. Aging 2012, 33, 430.e19-430.e33. [CrossRef] [PubMed]

85. Li Puma, D.D.; Piacentini, R.; Leone, L.; Gironi, K.; Marcocci, M.E.; De Chiara, G.; Palamara, A.T.; Grassi, C. Herpes Simplex Virus Type-1 Infection Impairs Adult Hippocampal Neurogenesis via Amyloid-beta Protein Accumulation. Stem Cells 2019, 37, 1467-1480. [CrossRef] [PubMed]

86. Piacentini, R.; Li Puma, D.D.; Ripoli, C.; Marcocci, M.E.; De Chiara, G.; Garaci, E.; Palamara, A.T.; Grassi, C. Herpes Simplex Virus type-1 infection induces synaptic dysfunction in cultured cortical neurons via GSK-3 activation and intraneuronal amyloid-beta protein accumulation. Sci. Rep. 2015, 5, 15444. [CrossRef] [PubMed]

87. Kristen, H.; Santana, S.; Sastre, I.; Recuero, M.; Bullido, M.J.; Aldudo, J. Herpes simplex virus type 2 infection induces AD-like neurodegeneration markers in human neuroblastoma cells. Neurobiol. Aging 2015, 36, 2737-2747. [CrossRef] [PubMed]

88. Miklossy, J.; Kis, A.; Radenovic, A.; Miller, L.; Forro, L.; Martins, R.; Reiss, K.; Darbinian, N.; Darekar, P.; Mihaly, L.; et al. Beta-amyloid deposition and Alzheimer's type changes induced by Borrelia spirochetes. Neurobiol. Aging 2006, 27, 228-236. [CrossRef] [PubMed]

89. Nie, R.; Wu, Z.; Ni, J.; Zeng, F.; Yu, W.; Zhang, Y.; Kadowaki, T.; Kashiwazaki, H.; Teeling, J.L.; Zhou, Y. Porphyromonas gingivalis Infection Induces Amyloid-beta Accumulation in Monocytes/Macrophages. J. Alzheimer's Dis. 2019, 72, 479-494. [CrossRef] [PubMed]

90. Cheng, S.B.; Ferland, P.; Webster, P.; Bearer, E.L. Herpes simplex virus dances with amyloid precursor protein while exiting the cell. PLOS ONE 2011, 6, e17966. [CrossRef] [PubMed]

91. Green, D.A.; Masliah, E.; Vinters, H.V.; Beizai, P.; Moore, D.J.; Achim, C.L. Brain deposition of beta-amyloid is a common pathologic feature in HIV positive patients. AIDS 2005, 19, 407-411. [CrossRef]

92. Khan, M.B.; Lang, M.J.; Huang, M.B.; Raymond, A.; Bond, V.C.; Shiramizu, B.; Powell, M.D. Nef exosomes isolated from the plasma of individuals with HIV-associated dementia (HAD) can induce A $\beta(1-42)$ secretion in SH-SY5Y neural cells. J. Neurovirol. 2016, 22, 179-190. [CrossRef]

93. Lopatko Lindman, K.; Weidung, B.; Olsson, J.; Josefsson, M.; Kok, E.; Johansson, A.; Eriksson, S.; Hallmans, G.; Elgh, F.; Lövheim, H. A genetic signature including apolipoprotein E⿺4 potentiates the risk of herpes simplex-associated Alzheimer's disease. Alzheimers Dement 2019, 5, 697-704. [CrossRef]

94. Itzhaki, R.F.; Lin, W.R.; Shang, D.; Wilcock, G.K.; Faragher, B.; Jamieson, G.A. Herpes simplex virus type 1 in brain and risk of Alzheimer's disease. Lancet 1997, 349, 241-244. [CrossRef]

95. Burgos, J.S.; Ramirez, C.; Sastre, I.; Bullido, M.J.; Valdivieso, F. ApoE4 is more efficient than E3 in brain access by herpes simplex virus type 1 . Neuroreport 2003, 14, 1825-1827. [CrossRef] [PubMed] 
96. Wozniak, M.A.; Mee, A.P.; Itzhaki, R.F. Herpes simplex virus type 1 DNA is located within Alzheimer's disease amyloid plaques. J. Pathol. 2009, 217, 131-138. [CrossRef] [PubMed]

97. Bitting, L.; Naidu, A.; Cordell, B.; Murphy, G.M., Jr. Beta-amyloid peptide secretion by a microglial cell line is induced by beta-amyloid-(25-35) and lipopolysaccharide. J. Biol. Chem. 1996, 271, 16084-16089. [CrossRef]

98. Soscia, S.J.; Kirby, J.E.; Washicosky, K.J.; Tucker, S.M.; Ingelsson, M.; Hyman, B.; Burton, M.A.; Goldstein, L.E.; Duong, S.; Tanzi, R.E.; et al. The Alzheimer's disease-associated amyloid beta-protein is an antimicrobial peptide. PLoS ONE 2010, 5, e9505. [CrossRef]

99. Soragni, A.; Yousefi, S.; Stoeckle, C.; Soriaga, A.B.; Sawaya, M.R.; Kozlowski, E.; Schmid, I.; Radonjic-Hoesli, S.; Boutet, S.; Williams, G.J.; et al. Toxicity of eosinophil MBP is repressed by intracellular crystallization and promoted by extracellular aggregation. Mol. Cell 2015, 57, 1011-1021. [CrossRef]

100. Pastore, A.; Raimondi, F.; Rajendran, L.; Temussi, P.A. Why does the A $\beta$ peptide of Alzheimer share structural similarity with antimicrobial peptides? Commun. Biol. 2020, 3, 135. [CrossRef] [PubMed]

101. Dicks, L.M.T.; Dreyer, L.; Smith, C.; van Staden, A.D. A Review: The Fate of Bacteriocins in the Human Gastro-Intestinal Tract: Do They Cross the Gut-Blood Barrier? Front. Microbiol. 2018, 9, 2297. [CrossRef]

102. Williams, W.M.; Torres, S.; Siedlak, S.L.; Castellani, R.J.; Perry, G.; Smith, M.A.; Zhu, X. Antimicrobial peptide $\beta$-defensin-1 expression is upregulated in Alzheimer's brain. J. Neuroinflamm. 2013, 10, 127. [CrossRef]

103. White, M.R.; Kandel, R.; Tripathi, S.; Condon, D.; Qi, L.; Taubenberger, J.; Hartshorn, K.L. Alzheimer's associated $\beta$-amyloid protein inhibits influenza A virus and modulates viral interactions with phagocytes. PLoS ONE 2014, 9, e101364. [CrossRef]

104. Eimer, W.A.; Vijaya Kumar, D.K.; Navalpur Shanmugam, N.K.; Rodriguez, A.S.; Mitchell, T.; Washicosky, K.J.; György, B.; Breakefield, X.O.; Tanzi, R.E.; Moir, R.D. Alzheimer's Disease-Associated $\beta$-Amyloid Is Rapidly Seeded by Herpesviridae to Protect against Brain Infection. Neuron 2018, 99, 56-63. [CrossRef] [PubMed]

105. Spitzer, P.; Condic, M.; Herrmann, M.; Oberstein, T.J.; Scharin-Mehlmann, M.; Gilbert, D.F.; Friedrich, O.; Grömer, T.; Kornhuber, J.; Lang, R.; et al. Amyloidogenic amyloid- $\beta$-peptide variants induce microbial agglutination and exert antimicrobial activity. Sci. Rep. 2016, 6, 32228. [CrossRef] [PubMed]

106. Kumar, D.K.V.; Choi, S.H.; Washicosky, K.J.; Eimer, W.A.; Tucker, S.; Ghofrani, J.; Lefkowitz, A.; McColl, G.; Goldstein, L.E.; Tanzi, R.E.; et al. Amyloid- $\beta$ peptide protects against microbial infection in mouse and worm models of Alzheimer's disease. Sci. Transl. Med. 2016, 8. [CrossRef]

107. Dominguez, D.; Tournoy, J.; Hartmann, D.; Huth, T.; Cryns, K.; Deforce, S.; Serneels, L.; Camacho, I.E.; Marjaux, E.; Craessaerts, K.; et al. Phenotypic and Biochemical Analyses of BACE1- and BACE2-deficient Mice. J. Biol. Chem. 2005, 280, 30797-30806. [CrossRef] [PubMed]

108. Bishop, G.M.; Robinson, S.R. The amyloid hypothesis: Let sleeping dogmas lie? Neurobiol. Aging 2002, 23, 1101-1105. [CrossRef]

109. Robinson, S.R.; Bishop, G.M. Abeta as a bioflocculant: Implications for the amyloid hypothesis of Alzheimer's disease. Neurobiol. Aging 2002, 23, 1051-1072. [CrossRef]

110. Bourgade, K.; Dupuis, G.; Frost, E.H.; Fülöp, T., Jr. Anti-Viral Properties of Amyloid- $\beta$ Peptides. J. Alzheimer's Dis. 2016, 54, 859-878. [CrossRef]

111. Gnann, J.W., Jr.; Barton, N.H.; Whitley, R.J. Acyclovir: Mechanism of action, pharmacokinetics, safety and clinical applications. Pharmacotherapy 1983, 3, 275-283. [CrossRef] [PubMed]

112. Wozniak, M.A.; Frost, A.L.; Preston, C.M.; Itzhaki, R.F. Antivirals reduce the formation of key Alzheimer's disease molecules in cell cultures acutely infected with herpes simplex virus type 1. PLoS ONE 2011, 6, e25152. [CrossRef]

113. Zambrano, A.; Solis, L.; Salvadores, N.; Cortes, M.; Lerchundi, R.; Otth, C. Neuronal cytoskeletal dynamic modification and neurodegeneration induced by infection with herpes simplex virus type 1. J. Alzheimer's Dis. 2008, 14, 259-269. [CrossRef]

114. Hui, Z.; Zhijun, Y.; Yushan, Y.; Liping, C.; Yiying, Z.; Difan, Z.; Chunglit, C.T.; Wei, C. The combination of acyclovir and dexamethasone protects against Alzheimer's disease-related cognitive impairments in mice. Psychopharmacology 2020. [CrossRef] [PubMed]

115. Prasad, K.M.; Eack, S.M.; Keshavan, M.S.; Yolken, R.H.; Iyengar, S.; Nimgaonkar, V.L. Antiherpes virus-specific treatment and cognition in schizophrenia: A test-of-concept randomized double-blind placebo-controlled trial. Schizophr. Bull. 2013, 39, 857-866. [CrossRef] 
116. Devanand, D.P.; Andrews, H.; Kreisl, W.C.; Razlighi, Q.; Gershon, A.; Stern, Y.; Mintz, A.; Wisniewski, T.; Acosta, E.; Pollina, J.; et al. Antiviral therapy: Valacyclovir Treatment of Alzheimer's Disease (VALAD) Trial: Protocol for a randomised, double-blind, placebo-controlled, treatment trial. BMJ Open 2020, 10, e032112. [CrossRef] [PubMed]

117. Wozniak, M.A.; Frost, A.L.; Itzhaki, R.F. The helicase-primase inhibitor BAY 57-1293 reduces the Alzheimer's disease-related molecules induced by herpes simplex virus type 1. Antivir. Res. 2013, 99, 401-404. [CrossRef] [PubMed]

118. Baumeister, J.; Fischer, R.; Eckenberg, P.; Henninger, K.; Ruebsamen-Waigmann, H.; Kleymann, G. Superior efficacy of helicase-primase inhibitor BAY 57-1293 for herpes infection and latency in the guinea pig model of human genital herpes disease. Antivir. Chem. Chemother. 2007, 18, 35-48. [CrossRef] [PubMed]

119. Betz, U.A.; Fischer, R.; Kleymann, G.; Hendrix, M.; Rubsamen-Waigmann, H. Potent in vivo antiviral activity of the herpes simplex virus primase-helicase inhibitor BAY 57-1293. Antimicrob. Agents Chemother. 2002, 46, 1766-1772. [CrossRef]

120. Kleymann, G. Helicase primase: Targeting the Achilles heel of herpes simplex viruses. Antivir. Chem. Chemother. 2004, 15, 135-140. [CrossRef]

121. Kleymann, G.; Fischer, R.; Betz, U.A.; Hendrix, M.; Bender, W.; Schneider, U.; Handke, G.; Eckenberg, P.; Hewlett, G.; Pevzner, V.; et al. New helicase-primase inhibitors as drug candidates for the treatment of herpes simplex disease. Nat. Med. 2002, 8, 392-398. [CrossRef]

122. Hayashi, K.; Hayashi, T.; Morita, N. Mechanism of action of the antiherpesvirus biflavone ginkgetin. Antimicrob. Agents Chemother. 1992, 36, 1890-1893. [CrossRef]

123. Miki, K.; Nagai, T.; Suzuki, K.; Tsujimura, R.; Koyama, K.; Kinoshita, K.; Furuhata, K.; Yamada, H.; Takahashi, K. Anti-influenza virus activity of biflavonoids. Bioorganic Med. Chem. Lett. 2007, 17, 772-775. [CrossRef]

124. Borenstein, R.; Hanson, B.A.; Markosyan, R.M.; Gallo, E.S.; Narasipura, S.D.; Bhutta, M.; Shechter, O.; Lurain, N.S.; Cohen, F.S.; Al-Harthi, L.; et al. Ginkgolic acid inhibits fusion of enveloped viruses. Sci. Rep. 2020, 10, 4746. [CrossRef] [PubMed]

125. Lee, J.H.; Kim, Y.G.; Ryu, S.Y.; Cho, M.H.; Lee, J. Ginkgolic acids and Ginkgo biloba extract inhibit Escherichia coli O157:H7 and Staphylococcus aureus biofilm formation. Int. J. Food Microbiol. 2014, 174, 47-55. [CrossRef]

126. Bagla, V.P.; McGaw, L.J.; Elgorashi, E.E.; Eloff, J.N. Antimicrobial activity, toxicity and selectivity index of two biflavonoids and a flavone isolated from Podocarpus henkelii (Podocarpaceae) leaves. BMC Complementary Altern. Med. 2014, 14, 383. [CrossRef]

127. Zeng, Y.Q.; Wang, Y.J.; Zhou, X.F. Ginkgetin Ameliorates Neuropathological Changes in APP/PS1 Transgenical Mice Model. J. Prev. Alzheimer's Dis. 2016, 3, 24-29. [CrossRef]

128. Kang, S.S.; Lee, J.Y.; Choi, Y.K.; Song, S.S.; Kim, J.S.; Jeon, S.J.; Han, Y.N.; Son, K.H.; Han, B.H. Neuroprotective effects of naturally occurring biflavonoids. Bioorganic Med. Chem. Lett. 2005, 15, 3588-3591. [CrossRef] [PubMed]

129. Sasaki, H.; Kitoh, Y.; Tsukada, M.; Miki, K.; Koyama, K.; Juliawaty, L.D.; Hakim, E.H.; Takahashi, K.; Kinoshita, K. Inhibitory activities of biflavonoids against amyloid-beta peptide 42 cytotoxicity in PC-12 cells. Bioorganic Med. Chem. Lett. 2015, 25, 2831-2833. [CrossRef]

130. Balducci, C.; Forloni, G. Doxycycline for Alzheimer's Disease: Fighting beta-Amyloid Oligomers and Neuroinflammation. Front. Pharmacol. 2019, 10, 738. [CrossRef]

131. Merlini, G.; Ascari, E.; Amboldi, N.; Bellotti, V.; Arbustini, E.; Perfetti, V.; Ferrari, M.; Zorzoli, I.; Marinone, M.G.; Garini, P.; et al. Interaction of the anthracycline $4^{\prime}$-iodo-4'-deoxydoxorubicin with amyloid fibrils: Inhibition of amyloidogenesis. Proc. Natl. Acad. Sci. USA 1995, 92, 2959-2963. [CrossRef]

132. Balducci, C.; Santamaria, G.; La Vitola, P.; Brandi, E.; Grandi, F.; Viscomi, A.R.; Beeg, M.; Gobbi, M.; Salmona, M.; Ottonello, S.; et al. Doxycycline counteracts neuroinflammation restoring memory in Alzheimer's disease mouse models. Neurobiol. Aging 2018, 70, 128-139. [CrossRef]

133. Costa, R.; Speretta, E.; Crowther, D.C.; Cardoso, I. Testing the therapeutic potential of doxycycline in a Drosophila melanogaster model of Alzheimer disease. J. Biol. Chem. 2011, 286, 41647-41655. [CrossRef]

134. Gautieri, A.; Beeg, M.; Gobbi, M.; Rigoldi, F.; Colombo, L.; Salmona, M. The Anti-Amyloidogenic Action of Doxycycline: A Molecular Dynamics Study on the Interaction with Abeta42. Int. J. Mol. Sci. 2019, 20, 4641. [CrossRef] [PubMed]

135. Loeb, M.B.; Molloy, D.W.; Smieja, M.; Standish, T.; Goldsmith, C.H.; Mahony, J.; Smith, S.; Borrie, M.; Decoteau, E.; Davidson, W.; et al. A randomized, controlled trial of doxycycline and rifampin for patients with Alzheimer's disease. J. Am. Geriatr. Soc. 2004, 52, 381-387. [CrossRef] [PubMed] 
136. Molloy, D.W.; Standish, T.I.; Zhou, Q.; Guyatt, G. A multicenter, blinded, randomized, factorial controlled trial of doxycycline and rifampin for treatment of Alzheimer's disease: The DARAD trial. Int. J. Geriatr. Psychiatry 2013, 28, 463-470. [CrossRef] [PubMed]

137. Mandal, A.; Sinha, C.; Kumar Jena, A.; Ghosh, S.; Samanta, A. An Investigation on in vitro and in vivo Antimicrobial Properties of the Antidepressant: Amitriptyline Hydrochloride. Braz. J. Microbiol. 2010, 41, 635-645. [CrossRef]

138. Wang, J.; Zhao, Z.; Lin, E.; Zhao, W.; Qian, X.; Freire, D.; Bilski, A.E.; Cheng, A.; Vempati, P.; Ho, L.; et al. Unintended effects of cardiovascular drugs on the pathogenesis of Alzheimer's disease. PLoS ONE 2013, 8, e65232. [CrossRef]

139. Yulug, B.; Hanoglu, L.; Kilic, E.; Schabitz, W.R. RIFAMPICIN: An antibiotic with brain protective function. Brain Res. Bull. 2014, 107, 37-42. [CrossRef]

140. Yulug, B.; Hanoglu, L.; Ozansoy, M.; Isık, D.; Kilic, U.; Kilic, E.; Schabitz, W.R. Therapeutic role of rifampicin in Alzheimer's disease. Psychiatry Clin. Neurosci. 2018, 72, 152-159. [CrossRef]

141. Bi, W.; Zhu, L.; Jing, X.; Liang, Y.; Tao, E. Rifampicin and Parkinson's disease. Neurol. Sci. 2013, 34, $137-141$. [CrossRef]

142. Tomiyama, T.; Asano, S.; Suwa, Y.; Morita, T.; Kataoka, K.; Mori, H.; Endo, N. Rifampicin prevents the aggregation and neurotoxicity of amyloid beta protein in vitro. Biochem. Biophys. Res. Commun. 1994, 204, 76-83. [CrossRef]

143. Tomiyama, T.; Shoji, A.; Kataoka, K.; Suwa, Y.; Asano, S.; Kaneko, H.; Endo, N. Inhibition of amyloid beta protein aggregation and neurotoxicity by rifampicin. Its possible function as a hydroxyl radical scavenger. J. Biol. Chem. 1996, 271, 6839-6844. [CrossRef]

144. Mindermann, T.; Landolt, H.; Zimmerli, W.; Rajacic, Z.; Gratzl, O. Penetration of rifampicin into the brain tissue and cerebral extracellular space of rats. J. Antimicrob. Chemother. 1993, 31, 731-737. [CrossRef] [PubMed]

145. Qosa, H.; Abuznait, A.H.; Hill, R.A.; Kaddoumi, A. Enhanced brain amyloid- $\beta$ clearance by rifampicin and caffeine as a possible protective mechanism against Alzheimer's disease. J. Alzheimer's Dis. 2012, 31, 151-165. [CrossRef]

146. Umeda, T.; Ono, K.; Sakai, A.; Yamashita, M.; Mizuguchi, M.; Klein, W.L.; Yamada, M.; Mori, H.; Tomiyama, T. Rifampicin is a candidate preventive medicine against amyloid- $\beta$ and tau oligomers. Brain 2016, 139, 1568-1586. [CrossRef]

147. Umeda, T.; Tanaka, A.; Sakai, A.; Yamamoto, A.; Sakane, T.; Tomiyama, T. Intranasal rifampicin for Alzheimer's disease prevention. Alzheimer's Dement. 2018, 4, 304-313. [CrossRef] [PubMed]

148. Li, N.; Collyer, C.A. Gingipains from Porphyromonas gingivalis-Complex domain structures confer diverse functions. Eur. J. Microbiol. Immunol. 2011, 1, 41-58. [CrossRef] [PubMed]

149. Curtis, M.A.; Kuramitsu, H.K.; Lantz, M.; Macrina, F.L.; Nakayama, K.; Potempa, J.; Reynolds, E.C.; Aduse-Opoku, J. Molecular genetics and nomenclature of proteases of Porphyromonas gingivalis. J. Periodontal Res. 1999, 34, 464-472. [CrossRef] [PubMed]

150. Guo, Y.; Nguyen, K.A.; Potempa, J. Dichotomy of gingipains action as virulence factors: From cleaving substrates with the precision of a surgeon's knife to a meat chopper-like brutal degradation of proteins. Periodontology 2000 2010, 54, 15-44. [CrossRef] [PubMed]

151. Potempa, J.; Banbula, A.; Travis, J. Role of bacterial proteinases in matrix destruction and modulation of host responses. Periodontology 2000 2000, 24, 153-192. [CrossRef]

152. Jagels, M.A.; Ember, J.A.; Travis, J.; Potempa, J.; Pike, R.; Hugli, T.E. Cleavage of the human C5A receptor by proteinases derived from Porphyromonas gingivalis: Cleavage of leukocyte C5a receptor. Adv. Exp. Med. Biol. 1996, 389, 155-164. [CrossRef]

153. Arastu-Kapur, S.; Nguyen, M.; Raha, D.; Ermini, F.; Haditsch, U.; Araujo, J.; De Lannoy, I.A.M.; Ryder, M.I.; Dominy, S.S.; Lynch, C.; et al. Treatment of Porphyromonas gulae infection and downstream pathology in the aged dog by lysine-gingipain inhibitor COR388. Pharmcol. Res. Perspect. 2020, 8, e00562. [CrossRef]

154. Payne, L.E.; Gagnon, D.J.; Riker, R.R.; Seder, D.B.; Glisic, E.K.; Morris, J.G.; Fraser, G.L. Cefepime-induced neurotoxicity: A systematic review. Crit. Care 2017, 21, 276. [CrossRef] [PubMed]

(C) 2020 by the authors. Licensee MDPI, Basel, Switzerland. This article is an open access article distributed under the terms and conditions of the Creative Commons Attribution (CC BY) license (http://creativecommons.org/licenses/by/4.0/). 